\title{
Update on the genetic and epigenetic etiology of gestational diabetes mellitus: a review
}

\author{
Tajudeen O. Yahaya ${ }^{*}$, Titilola Salisu², Yusuf B. Abdulrahman ${ }^{3}$ and Abdulrazak K. Umar ${ }^{3}$
}

\begin{abstract}
Background: Many studies have been conducted on the genetic and epigenetic etiology of gestational diabetes mellitus (GDM) in the last two decades because of the disease's increasing prevalence and role in global diabetes mellitus (DM) explosion. An update on the genetic and epigenetic etiology of GDM then becomes imperative to better understand and stem the rising incidence of the disease. This review, therefore, articulated GDM candidate genes and their pathophysiology for the awareness of stakeholders.
\end{abstract}

Main body (genetic and epigenetic etiology, GDM): The search discovered 83 GDM candidate genes, of which TCF7L2, MTNR1B, CDKAL1, IRS1, and KCNQ1 are the most prevalent. Certain polymorphisms of these genes can modulate beta-cell dysfunction, adiposity, obesity, and insulin resistance through several mechanisms. Environmental triggers such as diets, pollutants, and microbes may also cause epigenetic changes in these genes, resulting in a loss of insulin-boosting and glucose metabolism functions. Early detection and adequate management may resolve the condition after delivery; otherwise, it will progress to maternal type 2 diabetes mellitus (T2DM) and fetal configuration to future obesity and DM. This shows that GDM is a strong risk factor for T2DM and, in rare cases, type 1 diabetes mellitus (T1DM) and maturity-onset diabetes of the young (MODY). This further shows that GDM significantly contributes to the rising incidence and burden of DM worldwide and its prevention may reverse the trend.

Conclusion: Mutations and epigenetic changes in certain genes are strong risk factors for GDM. For affected individuals with such etiologies, medical practitioners should formulate drugs and treatment procedures that target these genes and their pathophysiology.

Keywords: Adiposity, Beta-cell dysfunction, Epigenetics, Insulin resistance, Obesity

\section{Background}

Pregnant women develop insulin resistance at certain stages owing to increased placenta hormones, but most women overcome this condition by up-regulating insulin production through beta cell expansion [1]. Gestational diabetes mellitus (GDM) begins when a pregnant female does not make the extra insulin needed to normalize blood glucose during the second or third trimester of pregnancy [1]. Sometimes the glucose intolerance may be present before pregnancy, but not diagnosed [2, 3]. Uncontrolled GDM can cause high blood pressure, type

\footnotetext{
*Correspondence: yahayatajudeen@gmail.com; yahaya.tajudeen@fubk.edu.ng ${ }^{1}$ Federal University Birnin Kebbi, PMB 1157 Birnin Kebbi, Nigeria

Full list of author information is available at the end of the article
}

2 diabetes mellitus (T2DM), and increased risks of vascular diseases in pregnant women $[4,5]$. Intrauterine exposure to high blood glucose may program the offspring to develop diabetes or obesity later in life [6]. It may also cause macrosomia, birth defects, preterm birth, and developmental delay [7-9].

GDM is the most common metabolic condition during pregnancy [10] with a global incidence rate between 1 and $28 \%$ [11]. In 2017, GDM affected about 204 million women worldwide with a projection to increase to 308 million by 2045 , mostly in developing countries [12]. Though most times the glucose intolerance normalizes soon after delivery, women with GDM have a high risk of developing T2DM later in life [13]. Compared to women with normal glucose tolerance, women with 
GDM are at least seven times more predisposed to T2DM [14]. Moreover, almost half of pregnant females with GDM will develop diabetes in a decade [14]. Offspring of women with GDM are also 8 times more prone to diabetes or pre-diabetes [15]. These show that GDM contributes immensely to the alarming incidence of diabetes worldwide [16]. Diabetes affected about 451 million people in 2017, of which 5 million died and USD 850 billion was spent on healthcare expenditure [17]. Considering the impact of GDM, the reduction of its prevalence and effective management of the affected will go a long way in stemming the incidence and burden of diabetes. However, to achieve a reduced prevalence of GDM, a proper understanding of its etiology is necessary. Fortunately, improved biological techniques in the last two decades have led to more understanding of the genetic and epigenetic etiology of the disease, thus an update becomes necessary. This review therefore articulated current findings on the genetic and epigenetic etiology of GDM.

\section{Methods}

\section{Databases searched}

An in-depth search of PubMed, Scopus, SpringerLink, Google Scholar, and ResearchGate databases was performed for relevant research articles on GDM.

\section{Search terms}

Some search terms used to retrieve articles are gestational diabetes mellitus, hyperglycemia, insulin resistance, obesity, glucose metabolism, beta-cell dysfunction, and gestational diabetes genes. Other search terms used include glucose insensitivity, epigenetics of diabetes mellitus, gestational diabetes testing and cost-effectiveness, and the prevalence of gestational diabetes.

\section{Article inclusion criteria}

Inclusion criteria include the following:

Research published in the English language.

Research that focused on GDM.

Studies that focused on the genetic and epigenetic etiology of GDM.

Articles that centered on GDM testing and costeffectiveness.

Studies published between 2000 till date.

\section{Article exclusion criteria}

Exclusion criteria include the following:

Studies that are not available in English language.

Studies with only abstract available.

Research that described GDM, but with no clear genetic and epigenetic mechanisms

Studies published before the year 2000 .

\section{Results}

Genetic etiology in GDM

The search found that mutations in some genes, or their variants, may interact with one another and environmental triggers to cause GDM (Fig. 1). The genetic etiology of GDM overlaps with T2DM, as most of the GDM candidate genes also predispose humans to T2DM. This explains the common pathophysiology of GDM and T2DM as both express beta-cell dysfunction and abnormal glucose metabolism [18]. Contrary to some reports, GDM also shares common pathophysiology with type 1 diabetes mellitus (T1DM) and maturity-onset diabetes of the young (MODY), but less than $10 \%$ of GDM patients show these associations [18].

Though many genes reportedly showed an association with obesity, insulin resistance, and beta-cell dysfunction, the present study discovered only 83 genes with a clear GDM pathophysiology and are presented in Table 1.

\section{Most frequent GDM candidate genes}

The list of GDM candidate genes is inexhaustible as more genes are continually discovered; however, certain genes are most often linked with the disease. Table 2 shows the most frequent GDM candidate genes and their variants in various ethnic groups.

From Table 2, we used a pie chart (Fig. 2) to express the percentage occurrence of each gene based on ethnicity. TCF7L2 gene was the most frequent having present in $17 \%$ of the ethnics, followed by MTNR $1 B$ with $15 \%$, CDKAL1 $10 \%$, KCNQ1 $10 \%$, and IRS1 $10 \%$. Some other genes are not widespread, but are often found in certain ethnics or regions. These genes include $Z R A N B 3$, found in Africa [96]; $A B C C 8$ found among Finnish [119]; Chemerin, found among Iranians [120]; and INS, found among the Greeks [121]. These genes can be used to develop a genetic testing guideline to predict the likelihood of GDM or determine its genetic and epigenetic etiology. This is important because there is no genetic testing procedure yet for GDM, partly because the condition is multifactorial in which several genes interact with environmental triggers to cause the disease. Thus, a mutation in a single gene may not explain full susceptibility to GDM and testing for all the candidate genes will be expensive and cumbersome. The low prevalence of GDM in the past also contributes to the lack of interest in developing a genetic testing guideline for the disease.

\section{Epigenetic etiology in GDM}

Epigenetics refers to the study of heritable changes in biological processes caused by modification of chemical tags on DNA such as methyl and ethyl groups [122]. These modifications are mediated by some mechanisms, including DNA methylation, histone modification, and 


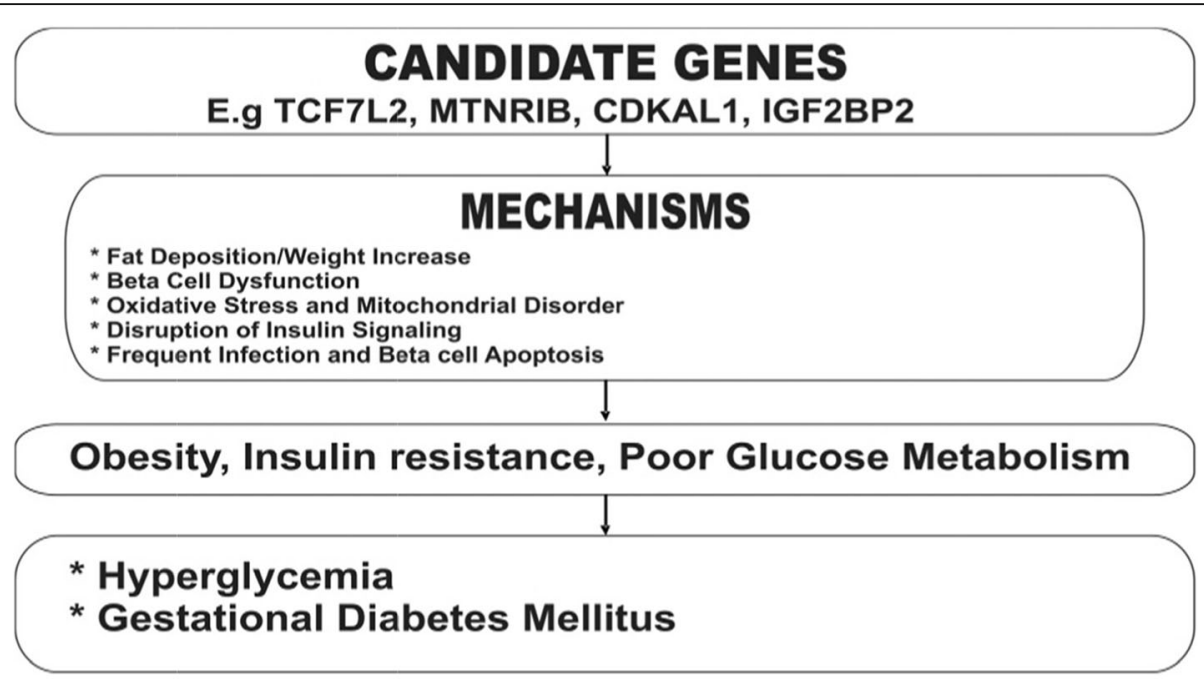

Fig. 1 Genetic etiology of gestational diabetes mellitus

microRNA expression [122]. Epigenetic mechanisms play important roles in several cellular activities, but certain environmental triggers can reprogram the epigenome, resulting in disease pathologies [123]. In particular, epigenetic mechanisms regulate several genes that maintain beta-cell morphology, proliferation, and functions, thus implies that epigenetic modification may disrupt insulin secretion and sensitivity, causing metabolic diseases, including GDM [124, 125]. Epigenetic changes are expressed in both somatic and gamete cells, and thus can be transmitted from generation to generation [126].

Studies have reported many instances of epigenetic modifications involving insulin synthesis and glucose metabolism in GDM. For instance, histone under-acetylation and overmethylation in the promoter region of the PDX1 gene reduce the insulin-boosting function of the gene [127]. Also, in a study that examined the methylation of the $I L-10$ gene among pregnant women, hypo-methylation of maternal blood cells and elevated plasma $I L-10$ levels were noticed in women with GDM [128]. In another study that compared the miRNA profiles of some diabetic pregnant rats with nondiabetic, repression of $m i R-338$ and overexpression of miR-451 were associated with reduced $\beta$-cell mass in the diabetic [129]. In vitro upregulation of miR-451 and repression of miR-338 in the same study increased $\beta$-cell mass, leading to improved glucose metabolism [129]. In a study that investigated the miRNA expressions of maternal and fetal blood cells of some pregnant women, 29 miRNAs were upregulated in individuals with GDM [130]. Of these miRNAs, miRNA-340 was confirmed to downregulate the expression of the PAIP1 gene [130]. In vitro normalization of the miRNA-340 expression of the diabetic mothers increased insulin production [130].
Environmental triggers of genetic and epigenetic etiology of GDM

Both the genetic and epigenetic etiology of GDM are mediated by certain environmental triggers that change gene functions. The genetic triggers mutate the genes, while the epigenetic triggers affect the chemical tags on the DNA without affecting the nucleotide sequence (Fig. 3). Among the environmental triggers are pollution and microbial exposures, whose GDM modulatory roles have been established by several studies. In a study that monitored the effects of air pollution among pregnant Southern Californians, prepregnancy exposures to nitrogen dioxide $\left(\mathrm{NO}_{2}\right)$, particulate matter (PM2.5 and PM10), and dioxin were related to GDM [131]. Nitrogen dioxide and particulate matter can cause oxidative stress, overexpression of proinflammatory cytokines, and endothelial dysfunction, resulting in increased insulin resistance [132]. Dioxin compounds can interact with peroxisome proliferatoractivated receptor- $\gamma$ (PPARG), disrupting insulin signaling pathways and resulting in insulin resistance and abnormal glucose metabolism [133]. Exposure to pathogenic microbial organisms may disrupt the gut microbiota and compromise the immune system, leading to metabolic disorders and GDM. Vu et al. [134] demonstrated in rabbits that a toxin produced by Staphylococcus aureus may interact with fat cells and the immune system, resulting in inflammation, insulin resistance and glucose intolerance [134]. In a study of the microbiota of some pregnant women, individuals with GDM showed gut microbiota imbalance containing majorly the phylum Actinobacteria and the genus Collinsella, Rothia and Desulfovibrio [135]. A balanced gut microbiota is necessary for optimum metabolism and the immune system. Aside from microbial infection, other environmental factors that may disrupt 
Table 1 GDM predisposing genes showing locations and phathophysiology

\begin{tabular}{|c|c|c|}
\hline Number & Gene & Full name \\
\hline 1 & TCF7L2 & Transcription factor 7-like 2 \\
\hline 2 & KCNQ1 & $\begin{array}{l}\text { Potassium voltage-gated channel sub- } \\
\text { family Q member } 1\end{array}$ \\
\hline 3 & $\begin{array}{l}\text { CENTD2/ } \\
\text { ARAP1 }\end{array}$ & $\begin{array}{l}\text { Centaurin-delta-2/ ArfGAP with rhoGAP } \\
\text { domain, ankyrin repeat and PH domain } \\
1\end{array}$ \\
\hline 4 & MTNR1B & Melatonin receptor $1 \mathrm{~B}$ \\
\hline 5 & IGF1 & Insulin-like growth factor 1 \\
\hline 6 & IGF2 & Insulin-like growth factor 2 \\
\hline 7 & IGFBP-1 & $\begin{array}{l}\text { Insulin like growth factor binding } \\
\text { protein } 1\end{array}$ \\
\hline 8 & IGFBP-2 & $\begin{array}{l}\text { Insulin like growth factor binding } \\
\text { protein } 3\end{array}$ \\
\hline 9 & IGF2BP2 & $\begin{array}{l}\text { Insulin like growth factor } 2 \text { mRNA } \\
\text { binding protein } 2\end{array}$ \\
\hline 10 & IGFBP-3 & $\begin{array}{l}\text { Insulin like growth factor binding } \\
\text { protein } 3\end{array}$ \\
\hline 11 & IGFBP-4 & $\begin{array}{l}\text { Insulin like growth factor binding } \\
\text { protein } 4\end{array}$ \\
\hline 12 & IGFBP5 & $\begin{array}{l}\text { Insulin like growth factor binding } \\
\text { protein } 5\end{array}$ \\
\hline 13 & PPARG & $\begin{array}{l}\text { Peroxisome proliferator-activated recep- } \\
\text { tor gamma }\end{array}$ \\
\hline 14 & KCNJ11 & $\begin{array}{l}\text { Potassium voltage-gated channel sub- } \\
\text { family J member } 11\end{array}$ \\
\hline 15 & INSR & Insulin receptor \\
\hline 16 & ADRB2 & Adrenoceptor beta 2 \\
\hline
\end{tabular}

$\begin{array}{ll}10 \mathrm{q} 2 & \text { Increases apoptosis, impairing insulin secretion [19]. } \\ 11 \mathrm{p} 15.5- & \text { It disrupts the influx of calcium into the channel, resulting in decreased } \\ 15.4 & \text { insulin secretion [20]. }\end{array}$

11q13.4 Causes disruption of glucose-induced insulin secretion [21].

11q14.3 Decreases insulin secretion, elevating fasting glucose levels [22].

12q23.2 Induces high body mass (HBM), leading to metabolic disturbances, especially insulin resistance and hyperinsulinemia [23].

11 15.5 Overexpression of IGF2 leads to $\beta$-cell dedifferentiation and endoplasmic reticulum stress, causing islet dysfunction [24].

7p12.3 Decreased blood levels of IGFBP-1 cause overexpression of IGF-I, resulting in inflammation [25].

2 q35 Reduced expression of IGFBP-2 inhibits adipogenesis, leading to obesity and insulin resistance [26].

3q27.2 Impairs $\beta$-cell function and modulates obesity, altering insulin sensitivity [27].

7p12.3 Overexpression of IGFBP-3 predisposes to HBM body, disrupting glucose metabolism [28].

17q21.2 Reduced levels cause HBM and insulin resistance [28].

2q35 Disrupts IGF-1 signaling pathway, leading to insulin insensitivity [29].

3p25.2 Stimulates abnormal fat deposition in tissues, causing obesity and insulin resistance [27].

11 p15.1 Reduces the sensitivity of pancreatic beta-cell KATP channel subunit (Kir6.2), resulting in decreased insulin release [28].

19p13.2 Predisposes to obesity, leading to insulin resistance [29].

$5 q 32$ Increases the secretion of vascular endothelial growth Factor-A (VEGF$A$ ) in the $\beta$-cells, resulting in hyper-vascularized islets and disrupting insulin secretion and glucose metabolism [30].

$17 \quad A D R B 3 \quad$ Adrenoceptor beta 3

8p11.23 Increases body weight, predisposing to obesity and insulin resistance [31].

12p13.31 Causes high-fat deposition and obesity [32].

11p15.1 Loss of function of the gene disrupts the KATP channel function, increasing the body weight and causing hyperinsulinism [33].

2q37.3 Increases body mass, initiating insulin resistance [34].

10q21.1 Causes frequent infections and chronic inflammatory diseases, leading to high-fat deposition and insulin resistance [35].

17p13.1 Impairs insulin signaling pathway [36].

10q23.33 Increases gluconeogenesis and impairs insulin signaling in muscles [37].

20q13.31 Induces high levels of fasting insulin, causing abnormal glucose metabolism [38].

5q13.1 Disrupts insulin signaling pathway in skeletal muscle and inhibit liver gluconeogenesis [38].

15q24.1 Promotes fat deposition, predisposing to obesity and insulin resistance [39].

$12 q 13$ Predisposes to obesity, causing metabolic disorder, especially insulin resistance $[40,41]$.

6p22.3 Inhibits the conversion of proinsulin to insulin through protein translation, leading to insulin resistance [42].

7p13 Increases body fat mass, resulting in insulin resistance [43]. 
Table 1 GDM predisposing genes showing locations and phathophysiology (Continued)

\begin{tabular}{|c|c|c|c|c|}
\hline Number & Gene & Full name & Locus & Pathophysiology \\
\hline 30 & CDKN2A/2B & Cyclin-dependent kinase inhibitor $2 a$ & $9 p 21.3$ & $\begin{array}{l}\text { Affects proinsulin conversion to insulin and reduces insulin sensitivity } \\
\text { [44]. }\end{array}$ \\
\hline 31 & $S R R$ & Serine racemase & $17 p 13.3$ & Disrupts the secretion of insulin and/or glucagon [45]. \\
\hline 32 & HHEX/IDE & Hematopoietically expressed homeobox & $10 q 23.33$ & Causes pancreatic and liver developmental error [46]. \\
\hline 33 & SLC30A8 & Solute carrier family 30 member 8 & $8 q 24.11$ & $\begin{array}{l}\text { Modulates loss of zinc in the beta cells, destabilizing insulin molecule } \\
s[47] \text {. }\end{array}$ \\
\hline 34 & LEP & Leptin & $7 q 31.3$ & Promotes inflammation, causing energy imbalance and obesity [48]. \\
\hline 35 & $\angle E P R$ & leptin receptor & $1 \mathrm{p} 31$ & Induces high-fat mass and insulin resistance [49]. \\
\hline 36 & HNF1B/TCF2 & Hepatocyte nuclear factor 1B & $17 q 12$ & Causes $\beta$-cell dysfunction $[50,51]$. \\
\hline 37 & TNF- $a$ TTNF & Tumor necrosis factor-a & $6 \mathrm{p} 21.33$ & Causes inflammatory and oxidative stress [52]). \\
\hline 38 & HNF4A/TCF1 & Hepatocyte nuclear factor 4 alpha & $20 q 12$ & Induces $\beta$-cell dysfunction $[50,51]$. \\
\hline 39 & WFS1 & Wolfram syndrome 1 & $4 p 16.1$ & $\begin{array}{l}\text { Initiates endoplasmic reticulum stress and mitochondrial disorder, } \\
\text { leading to } \beta \text {-cell dysfunction [53]. }\end{array}$ \\
\hline 40 & IRSI & insulin receptor substrate 1 & $2 q 36.3$ & $\begin{array}{l}\text { Induces an inflammatory response and causing low insulin sensitivity } \\
\text { [54]. }\end{array}$ \\
\hline 41 & $\begin{array}{l}\text { HTR2B/ 5-HT- } \\
1 A\end{array}$ & 5-hydroxytryptamine receptor 1a & $5 q 12.3$ & Reduces beta-cell proliferation and increases body weight [55]. \\
\hline 42 & TPH1 & Tryptophan hydroxylase 1 & $11 \mathrm{p} 15.1$ & $\begin{array}{l}\text { Causes low levels of serotonin, increasing weight gain and causing } \\
\text { insulin intolerance [56]. }\end{array}$ \\
\hline 43 & $\begin{array}{l}\text { 5-HT1A } \\
\text { HTR3A }\end{array}$ & 5-hydroxytryptamine receptor 1a & $5 q 12.3$ & Causes low serotonin levels, resulting in insulin resistance [57]. \\
\hline 44 & HNFTA & Hepatocyte nuclear factor-1 alpha & $12 \mathrm{q} 24.31$ & $\begin{array}{l}\text { Causes adiposity, leading to pre-pregnancy obesity and insulin resist- } \\
\text { ance [57]. }\end{array}$ \\
\hline 45 & GCKR & Glucokinase regulator & $2 \mathrm{p} 23.3$ & $\begin{array}{l}\text { Overexpression of GCKR causes hyperactivity of GCK, reducing glucose } \\
\text { and increasing fat accumulation [58]. Loss of the function reduces GCK } \\
\text { expression, impairing glucose clearance [59]. }\end{array}$ \\
\hline 46 & MIF & Macrophage migration inhibitory factor & $22 q 11.23$ & $\begin{array}{l}\text { Overexpression of the MIF gene in placental tissue causes insulin } \\
\text { resistance [60]. }\end{array}$ \\
\hline 47 & $A D R A 2 A$ & Alpha-2-adrenergic receptors & 10q25.2 & Increases body fat mass, leading to loss of glucose regulation [61]. \\
\hline 48 & SLC6A4 & Solute carrier family 6 member 4 & $17 q 11.2$ & $\begin{array}{l}\text { Impairs serotonin metabolism, increasing body weight and causing } \\
\text { insulin resistance [62]. }\end{array}$ \\
\hline 49 & FTO & $\begin{array}{l}\text { Fat mass and obesity-associated gene/ } \\
\text { Alpha-ketoglutarate dependent } \\
\text { dioxygenase }\end{array}$ & $16 q 12.2$ & $\begin{array}{l}\text { Causes adiposity, leading to pre-pregnancy obesity and insulin resist- } \\
\text { ance [63]. }\end{array}$ \\
\hline 50 & TLE1 & Transducin-like enhancer of split-1 & $9 q 21.32$ & Elevates fasting glucose level and reduces insulin secretion [64]. \\
\hline 51 & $A D C Y 5$ & Adenylate cyclase 5 & $3 q 21.1$ & $\begin{array}{l}\text { Alters ADCY5 expression in pancreatic beta cells, impairing glucose } \\
\text { signaling [65]. }\end{array}$ \\
\hline 52 & $\| L-1 \beta$ & Interleukin-1 beta & $2 q 14.1$ & Impairs pancreatic $\beta$-cells, decreasing insulin secretion [66]. \\
\hline 53 & $\| L-6$ & Interleukin-6 & $7 p 15.3$ & $\begin{array}{l}\text { Overexpression destroys pancreatic } \beta \text {-cells, resulting in apoptosis and } \\
\text { low insulin synthesis [67]. }\end{array}$ \\
\hline 54 & IL-10 & Interleukin-10 & $1 \mathrm{q} 32.1$ & $\begin{array}{l}\text { Overexpression compromises immune response, disrupting insulin } \\
\text { metabolism [68]. }\end{array}$ \\
\hline 55 & PAX8 & Paired box 8 & $2 q 14.1$ & Reduces islet viability and beta cell survival [69]. \\
\hline 56 & $\begin{array}{l}\text { ADIPOQ } \\
\text { (diponectin } \\
\text { gene) }\end{array}$ & $\begin{array}{l}\text { Adiponectin, } \mathrm{C} 1 \mathrm{Q} \text { and collagen domain } \\
\text { containing }\end{array}$ & $3 q 27.3$ & Causes low adiponectin, leading to obesity and insulin resistance [70]. \\
\hline 57 & $\begin{array}{l}\text { RARRES2 } \\
\text { (Chemerin } \\
\text { gene) }\end{array}$ & retinoic acid receptor responder 2 & $7 q 36.1$ & $\begin{array}{l}\text { Initiates inflammation and energy imbalance, leading to obesity and } \\
\text { insulin resistance [71]. }\end{array}$ \\
\hline 58 & $\begin{array}{l}\text { SERPINA12 } \\
\text { (Vaspin gene) }\end{array}$ & Serpin family a member 12 & $14 q 32.13$ & Causes inflammation, loss of energy balance, and obesity [72]. \\
\hline 59 & RETN & Resistin & 19p13.2 & Causes a loss of energy balance, obesity, and insulin resistance [73]. \\
\hline
\end{tabular}


Table 1 GDM predisposing genes showing locations and phathophysiology (Continued)

\begin{tabular}{|c|c|c|c|c|}
\hline Number & Gene & Full name & Locus & Pathophysiology \\
\hline 60 & APLN & Apelin & Xq26.1 & Causes a loss of energy balance, obesity, and insulin resistance [74]. \\
\hline 61 & $\begin{array}{l}\text { NUCB2 } \\
\text { (nesfatin } 1 \\
\text { gene) }\end{array}$ & Nucleobindin 2 & $11 \mathrm{p} 15.1$ & Causes a loss of energy balance, obesity, and insulin resistance [75]. \\
\hline 62 & ITLN1 & Intelectin-1/Omentin-1 & $1 \mathrm{q} 23.3$ & Loss of function induces insulin resistance [76]. \\
\hline 63 & $\begin{array}{l}\text { NAMPT/PBEF1 } \\
\text { (Visfatin } \\
\text { gene) }\end{array}$ & Nicotinamide phosphoribosyltransferase & $7 q 22.3$ & Causes obesity and insulin resistance [76]. \\
\hline 64 & $\begin{array}{l}\text { HMG2OA } \\
\text { IBRAF }\end{array}$ & High mobility group protein 20a & $15 q 24.3$ & $\begin{array}{l}\text { Depletion represses expression of insulin-producing genes such as Neu- } \\
\text { roD, Mafa and GCK, and enhances beta-cell de-differentiating gene } \\
\text { such as PAX4 and REST [77]. }\end{array}$ \\
\hline 65 & RREB1 & $\begin{array}{l}\text { Ras responsive element binding protein } \\
1\end{array}$ & $6 \mathrm{p} 24.3$ & Causes fat deposition and beta cell dysfunction [78]. \\
\hline 66 & GLIS3 & GLIS family zinc finger 3 & $9 \mathrm{p} 24.2$ & Causes fat deposition and beta cell dysfunction [78]. \\
\hline 67 & GPSM1 & G protein signaling modulator 1 & $9 q 34.3$ & Causes fat deposition and beta cell dysfunction [78]. \\
\hline 68 & $m t D N A$ & Mitochondrial DNA & All cells & $\begin{array}{l}\text { Induces oxidative stress and mitochondrial disorder, causing insulin } \\
\text { resistance [79]. }\end{array}$ \\
\hline 69 & $P R L R$ & Prolactin receptor & $5 p 13.2$ & $\begin{array}{l}\text { Modulates loss of PRLR signaling in } \beta \text {-cells. reducing } \beta \text {-cell proliferation } \\
\text { and expansion during pregnancy [80]. }\end{array}$ \\
\hline 70 & MAFB & MAF bZIP transcription factor B & $20 q 12$ & Causes inadequate $\beta$-cell expansion [80]. \\
\hline 71 & SERT & Serotonin transporter & $\begin{array}{l}17 q 11.1- \\
12\end{array}$ & $\begin{array}{l}\text { Stimulates abnormal fat accumulation in both white and brown } \\
\text { adipose tissues, causing glucose intolerance and insulin resistance [81]. }\end{array}$ \\
\hline 72 & PAl-1 & Plasminogen activator inhibitor 1 & $7 q 22$ & $\begin{array}{l}\text { Predisposes to adiposity, increasing body weight and affecting } \\
\text { pancreatic beta-cell function [82]. }\end{array}$ \\
\hline 73 & TSPAN8 & Tetraspanin-8 & $12 q 21.1$ & Impairs gestational glucose tolerance [83]. \\
\hline 74 & G6PC2 & $\begin{array}{l}\text { Glucose-6-phosphatase catalytic subunit } \\
2\end{array}$ & $2 \mathrm{q} 31.1$ & Elevates fasting glucose level and reduces insulin secretion [64]. \\
\hline 75 & PTPRD & $\begin{array}{l}\text { Protein tyrosine phosphatase receptor } \\
\text { type d }\end{array}$ & $\begin{array}{l}9 \mathrm{p} 24.1- \\
\text { p23 }\end{array}$ & $\begin{array}{l}\text { Disrupts insulin signaling pathway, leading to altered insulin sensitivity } \\
\text { and glucose homeostasis [84]. }\end{array}$ \\
\hline 76 & $C R P$ & C-reactive protein & $1 q 23.2$ & $\begin{array}{l}\text { Overexpression causes obesity, resulting in systemic inflammation and } \\
\text { insulin resistance [85]. }\end{array}$ \\
\hline 77 & GK & Glycerol kinase & Xp21.2 & Deficiency causes abnormal insulin metabolism [86]. \\
\hline 78 & PAX4 & Paired box gene 4 & $7 q 32.1$ & $\begin{array}{l}\text { Impairs fetal islet cell differentiation, altering insulin sensitivity later in } \\
\text { life [87]. }\end{array}$ \\
\hline 79 & HDAC4 & Histone deacetylase 4 & $2 \mathrm{q} 37.3$ & $\begin{array}{l}\text { Causes } \beta \text {-cell loss, leading to decreased insulin secretion. Also represses } \\
\text { beta-cell transcriptional factors [88]. }\end{array}$ \\
\hline 80 & FETUA AHSG & Fetuin-a & $3 q 27.3$ & $\begin{array}{l}\text { Increases body mass, insulin secretion and C-peptide levels, but lower } \\
\text { insulin sensitivity [89]. }\end{array}$ \\
\hline 81 & FETUB & Fetuin-b & $3 q 27.3$ & $\begin{array}{l}\text { Increases hepatic steatosis, impairing insulin secretion and glucose } \\
\text { metabolism [90]. }\end{array}$ \\
\hline 82 & FGF21 & Fibroblast growth factor 21 & $10 q 26.13$ & $\begin{array}{l}\text { Cause an abnormal glucose metabolism independent of insulin } \\
\text { resistance [91]. }\end{array}$ \\
\hline 83 & SNORAB & & & An emerging candidate gene [92] \\
\hline
\end{tabular}

gut microbiota include certain diseases, oral microbiome, diets, and antibiotic use, among others [136].

Lifestyles such as short sleep, poor nutritional choices, advanced age, and physical inactivity are some environmental triggers that may predispose humans to GDM. Short hour sleep at night can increase body fat accumulation, reduce glucose metabolism, and predispose to T2DM and GDM. In a study that determines the frequency of GDM among sleep-deprived 668 Singaporeans, 131, representing $19 \%$, were diagnosed with GDM of which $27.3 \%$ sleep less than 6 hours a night, while $16.8 \%$ sleep between 7-8 hours [137]. Poor nutrition, such as energy-dense western diets may cause overweight and obesity, disrupting insulin signaling pathways and insulin sensitivity. Saturated fats can disrupt insulin signaling, induce inflammation and endothelial dysfunction, resulting in GDM. In a study that evaluated 
Table 2 Most prevalent gestational diabetes mellitus genes across countries, ethnicity, and race in the world

\begin{tabular}{|c|c|c|c|c|}
\hline Gene & Countries/ethnicity/race & Variants & Level of significance & $\overline{\text { References }}$ \\
\hline \multirow[t]{10}{*}{$\overline{\text { TCF7L2 }}$} & \multirow[t]{4}{*}{ Mexicans } & rs7901695 & $P=2.16 \times 10^{-6}$ & [93] \\
\hline & & rs7901696 & $P<0.05$ & [93] \\
\hline & & rs7901697 & $P<0.05$ & [93] \\
\hline & & rs7901698 & $P<0.05$ & [93] \\
\hline & Asians & rs7903146 & $P=0.001$ & [94] \\
\hline & Scandinavians & rs7903146 & $P<0.05$ & [95] \\
\hline & Africans & rs7903146 & $P=7.288 \times 10^{-13}$ & [96] \\
\hline & Hispanic/Latinos & rs7903146 & $P<0.05$ & [97] \\
\hline & Caucasians/Danish & rs7903146 & $P=0.00017$ & [98] \\
\hline & Caucasian & rs4506565 & $P<0.001$ & [99] \\
\hline \multirow[t]{8}{*}{ KCNQ1 } & \multirow[t]{3}{*}{ Mexicans } & rs2237892 & $P=1.98 \times 10^{-5}$ & [93] \\
\hline & & rs163184 & $P<0.05$ & [93] \\
\hline & & rs2237897 & $P<0.05$ & [93] \\
\hline & \multirow[t]{2}{*}{ Koreans } & rs2074196 & $P=0.039$ & {$[100]$} \\
\hline & & rs2237892 & $P<0.05$ & {$[100]$} \\
\hline & \multirow[t]{2}{*}{ East Asians } & rs2074196 & $P=0.039$ & {$[100]$} \\
\hline & & rs2237892 & $P<0.05$ & {$[100]$} \\
\hline & Pakistan & rs2237895 & $P<0.05$ & [101] \\
\hline \multirow[t]{8}{*}{ MTNRIB } & Mexicans & rs1387153 & $P=0.05358$ & [93] \\
\hline & Asians & rs10830963 & $P<0.001$ & [94] \\
\hline & Caucasians & rs10830963 & $P<0.001$ & [94] \\
\hline & Koreans & rs10830962 & $P=2.49 \times 10^{-13}$ & [102] \\
\hline & \multirow[t]{2}{*}{ Danish } & rs10830963 & $P<0.05$ & [103] \\
\hline & & rs1387153 & $P<0.05$ & [103] \\
\hline & \multirow[t]{2}{*}{ Saudi Arabians } & rs1387153 & $P<0.05$ & [104] \\
\hline & & rs10830963 & $P<0.05$ & [104] \\
\hline \multirow[t]{4}{*}{ PPARG } & Asians & rs1801282 & $P=0.011$ & [94] \\
\hline & \multirow[t]{2}{*}{ Caucasians } & rs1801282 & $P<0.05$ & [99] \\
\hline & & rs3856806 & $P<0.05$ & [99] \\
\hline & Caucasians/Danish & rs1801282 & $P<0.05$ & [98] \\
\hline \multirow[t]{4}{*}{ CDKAL1 } & Koreans & rs7754840 & $P=2.49 \times 10^{-13}$ & {$[102]$} \\
\hline & Caucasians & rs7756992 & $P<0.05$ & [99] \\
\hline & Caucasian/Danish & rs7756992 & $P=0.00017$ & [98] \\
\hline & Iranians & rs7754840 & $P<0.001$ & [105] \\
\hline \multirow[t]{4}{*}{ IRS1 } & Scandinavians & IRS1 Arg972 & $P<0.05$ & {$[106]$} \\
\hline & Americans & Arg972 & $P<0.05$ & [107] \\
\hline & Saudi Arabians & rs1801278 & $P=0.01$ & [108] \\
\hline & Austro-Hungarians & rs7578326 & $P<0.05$ & [109] \\
\hline \multirow[t]{3}{*}{ HMGA2 } & Africans & rs138066904 & $P=2.516 \times 10^{-9}$ & {$[96]$} \\
\hline & Africa Americans & rs343092 & $P<0.05$ & [96] \\
\hline & Europeans & rs2258238 & $P<0.05$ & {$[96]$} \\
\hline \multirow[t]{3}{*}{ IGF2BP2 } & Koreans & rs4402960 & $P<0.001$ & [110] \\
\hline & Caucasians/Danish & rs4402960 & $P<0.001$ & [111] \\
\hline & Chinese & rs4402960 & $P<0.001$ & {$[112]$} \\
\hline
\end{tabular}


Table 2 Most prevalent gestational diabetes mellitus genes across countries, ethnicity, and race in the world (Continued)

\begin{tabular}{|c|c|c|c|c|}
\hline Gene & Countries/ethnicity/race & Variants & Level of significance & References \\
\hline \multirow[t]{3}{*}{ GCKR } & Malaysians & rs780094 & $P<0.05$ & [113] \\
\hline & American Caucasians & rs780094 & $P<0.05$ & {$[114]$} \\
\hline & Brazilians & rs780094 & $P<0.05$ & {$[115]$} \\
\hline \multirow[t]{3}{*}{ FGF21 } & Iranians & Over expression of mRNA & $P<0.001$ & [116] \\
\hline & Chinese & Over expression of mRNA & $P<0.001$ & {$[117]$} \\
\hline & Australians & Over expression of mRNA & $P<0.001$ & [118] \\
\hline
\end{tabular}

the effect of dietary patterns among pregnant Chinese women, diets containing high protein and low starch were associated with a reduced risk of GDM [138]. Energy-dense diets are deficient in betaine, which is a methyl donor for methylating important biological processes and as well a substrate of methionine metabolism [139]. Diets low in betaine may induce abnormal methylation of some genes involved in insulin synthesis and glucose metabolism. Advanced age may also predispose pregnant women to GDM because mitochondrial functions decline with age, leading to reduced metabolic activities and an increased body mass index [140]. Aging changes the epigenetic pattern, affecting the expression of some genes involved in glucose metabolism, particularly the COX7A1 gene in the respiratory chain [141]. In a study of 1688 women in northwest London who developed GDM, advanced maternal age was linked to GDM [142]. Studies that demonstrate the role of physical inactivity in the pathogenesis of GDM are scarce. However, a systematic and meta-analysis by Ming et al. [143] shows that physical activity during pregnancy can decrease the occurrence of GDM, suggesting that lack of exercise is a risk factor. Some mechanisms through which inactivity

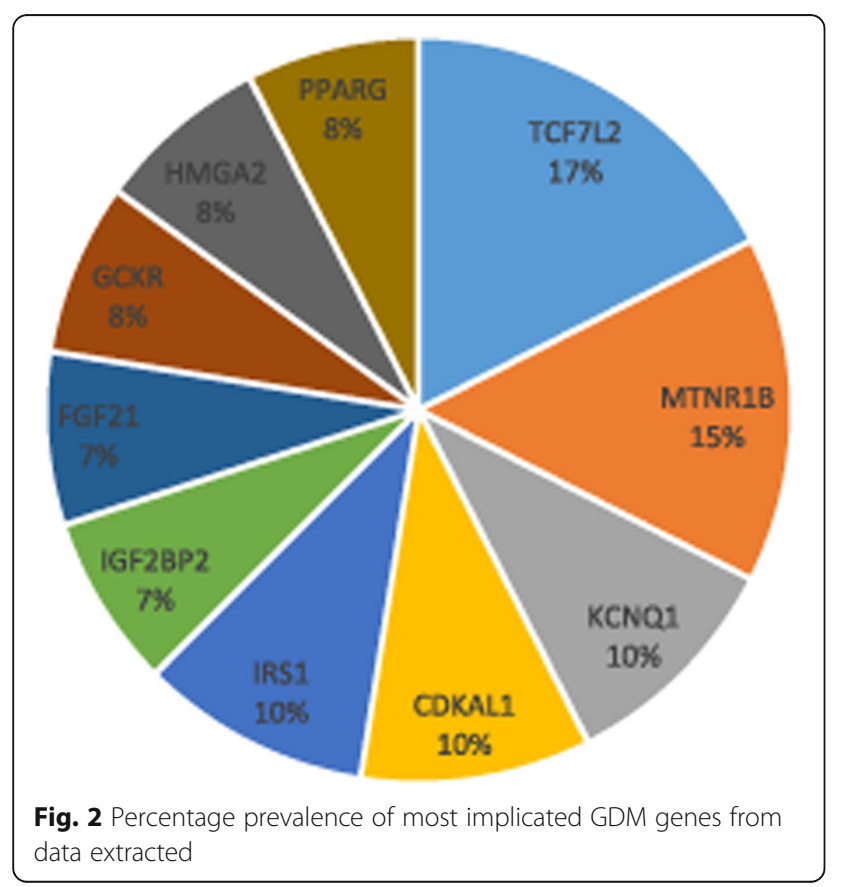

mediates diseases include mitochondrial dysfunction, changes in the composition of muscles, and insulin resistance, among others [144]. Physical inactivity influences the epigenome negatively, affecting several generations [145].

\section{GDM testing, efficacy, and cost-effectiveness}

Early detection of GDM is important to prevent its shortand long-term effects, especially the maternal progression to T2DM and fetal programming to DM later in life. Certain features such as BM1 above $30 \mathrm{~kg} / \mathrm{m}^{2}$ as well as previous GDM, baby birth weight of $4.5 \mathrm{~kg}$ or above, and macrosomia suggest a need for a GDM test [146]. Pregnant women with a family history of DM and ethnic groups with a high prevalence of DM such as Asian, Black, African-Caribbean or Middle Eastern should also consider the test $[146,147]$. As stated earlier, there is no genetic testing procedure yet for GDM, however, two tests, namely glucose challenge test (GCT) and oral glucose tolerance test (OGTT) are frequently conducted at 24-28 weeks of pregnancy to diagnose GDM. The two tests can be done in succession known as 2-step screening, or OGTT alone can be done called 1-step screening.

In the 2-step screening, the GCT (otherwise known as a glucose screening test) is done first and entails testing the blood glucose one hour after drinking a sweet substance without fasting. If the blood glucose is $140 \mathrm{mg} / \mathrm{dL}$ $(7.8 \mathrm{mmol} / \mathrm{L})$ or higher, then an OGTT is necessary [148]. The OGTT measures blood glucose after 8-hour fasting, after which a glucose substance $(75 \mathrm{~g})$ is taken and blood glucose re-measured after 1, 2 and 3 hours. High blood glucose levels at any two or more of the blood test times suggest GDM [148]. Though the pathophysiology of GDM are similar with T2DM, a GCT of $200 \mathrm{mg} / \mathrm{dL}$ or more could indicate T2DM [148].

Relatively recently, serum levels of C-reactive protein (CRP) as well as glycated hemoglobin (HbA1c) and random blood sugar (RBS) are used as screening tools for GDM in the first trimester. CRP concentrations of about $6 \mathrm{mg} / \mathrm{L}$ or higher in undiluted serum samples are considered positive for GDM [149]. According to the International Association of the Diabetes and Pregnancy Study Group (IADPSG), the cutoff level of HbA1c is 6.5 $\%$ and RBS is $11.1 \mathrm{mmol}(200 \mathrm{mg} / \mathrm{dL})$ [150]. 


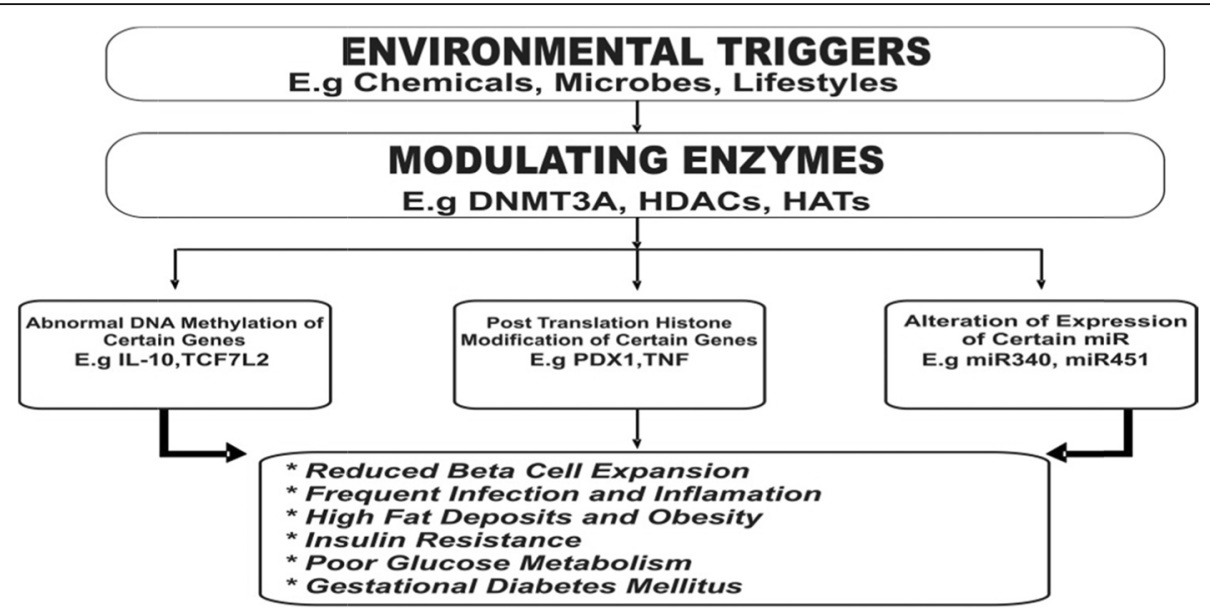

Fig. 3 Epigenetic etiology of gestational diabetes mellitus

The cost-effectiveness of GDM testing is controversial because it depends on the region, race, screening tools, and methods. A systematic review by Fitria [151] reported that GDM testing and controlling is not effective in high-income countries. This could be due to the low prevalence of the disease in the region and the allencompassing health care system. However, GDM testing could be worthwhile in countries with a high prevalence of GDM and nations with a poor healthcare system. For example, Marseille et al. [152] reported the cost-effectiveness of GDM testing using a devised model in Israel and India, which are known for high GDM incidence rates. The 2-step GTT is often recommended, however, a systematic review and meta-analysis by Saconne et al [153] showed no significant cost-effective difference between the two methods. The 2-step screening is also time-consuming and inconvenient, which may put off some patients [150, 154]. Glycated hemoglobin and RBS are simple GDM screening tools and are gaining acceptance worldwide, however, more awareness and understanding of the tools are necessary.

\section{Conclusion}

Several articles reviewed showed that mutation and epigenetic modifications in certain genes can predispose humans to GDM. Most of the GDM candidate genes identified have also been implicated in the pathogenesis of T2DM, and both diseases share a common pathophysiology. The two metabolic disorders expressed oxidative stress-induced beta-cell dysfunction and insulin resistance through adiposity and obesity. One major difference between GDM and T2DM is that it resolves most times after delivery, however, it may progress to T2DM if not checked. This shows that GDM is a strong risk factor for T2DM, thus, its detection and management may reduce the prevalence of DM worldwide. Of the GDM candidate genes identified, the variants of TCF7L2, MTNR1B,
CDKAL1, IRS1 and KCNQ1 are the most widespread, while some others are confined to certain ethnic groups. A genetic testing procedure can be developed around these genes to predict the likelihood of GDM or determine its genetic and epigenetic etiology. This will go a long way in stemming the incidence of DM worldwide.

\section{Abbreviations \\ CRP: C-reactive protein; DM: Diabetes mellitus; GCT: Glucose challenge test; GDM: Gestational diabetes mellitus; HbA1C: Glycated hemoglobin; IADPSG: International Association of the Diabetes and Pregnancy Study Group; MODY: Maturity onset diabetes of the young; $\mathrm{NO}_{2}$ : Nitrogen dioxide; OGTT: Oral glucose tolerance test; PM2.5: Particulate matter size 2.5; PM10: Particulate matter size 10; RBS: Random blood sugar; T1DM: Type 1 diabetes mellitus; T2DM: Type 2 diabetes mellitus}

\section{Acknowledgements}

None.

\section{Authors' contributions}

TY conceptualized, did the literature search, drafted the manuscript, and did correspondence. TS designed the article and did the literature search. YA did the article selection and proofreading. AU did the article selection and proofreading. All authors have read and approved the manuscript.

Funding

None.

Availability of data and materials

Not applicable.

Ethics approval and consent to participate

Not applicable.

Consent for publication

Not applicable.

\section{Competing interests}

The authors declare that they have no competing interests.

\section{Author details}

${ }^{1}$ Federal University Birnin Kebbi, PMB 1157 Birnin Kebbi, Nigeria. ${ }^{2}$ Department of Zoology and Environmental Biology, Olabisi Onabanjo University Ago-Iwoye, Ago-Iwoye, Ogun State, Nigeria. ${ }^{3}$ Department of Biochemistry and Molecular Biology, Federal University Birnin Kebbi, Birnin Kebbi, Nigeria. 
Received: 14 November 2019 Accepted: 11 February 2020 Published online: 23 March 2020

\section{References}

1. National Institute of Diabetes and Digestive and Kidney Diseases (NIDDK), Symptoms \& Causes of Gestational Diabetes. https://www.niddk.nih.gov/ health-information/diabetes/overview/what-is-diabetes/gestational/ symptoms-causes

2. Fernández-Morera JL, Rodríguez-Rodero S, Menéndez-Torre E et al (2010) The possible role of epigenetics in gestational diabetes: cause, consequence, or both. Obstet Gynecol Int. 2010:605163. https://doi.org/10. $1155 / 2010 / 605163$

3. American Diabetes Association (ADA). Standards of medical care in diabetes- 2018". Diabetes Care. 2018;41(Suppl 1):S13-S27, doi: https://doi. org/10.2337/dc18-S002

4. Rayanagoudar G, Hashi AA, Zamora J et al (2016) Quantification of the type 2 diabetes risk in women with gestational diabetes: a systematic review and meta-analysis of 95,750 women. Diabetologia 59:1403-1411. https://doi.org/ 10.1007/s00125-016-3927-2

5. Burlina S, Dalfrà MG, Lapolla A. Clinical and biochemical approach to predicting post-pregnancy metabolic decompensation. Diabetes Res Clin Pract, 2018;145:178-183. DOI:10.1016/j.diabres.2018.02.035. DOI: https://doi. org/10.1016/j.diabres.2018.02.035

6. Yessoufou A, Moutairou K. Maternal Diabetes in Pregnancy: Early and LongTerm Outcomes on the Offspring and the Concept of "Metabolic Memory. Experimental Diabetes Research, 2011; 2011: Article ID 218598. https://doi. org/10.1155/2011/218598.

7. Metzger BE (2009) The HAPO Study Cooperative Research Group. Hyperglycemia and Adverse Pregnancy Outcome (HAPO) study. Associations with neonatal anthropometrics. Diabetes 58:453-459. https:// doi.org/10.2337/db08-1112

8. Freinkel N (1980) Banting Lecture 1980: of pregnancy and progeny. Diabetes 29:1023-1035

9. Farahvar S, Walfisch A, Sheiner E (2019) Gestational diabetes risk factors and long-term consequences for both mother and offspring: a literature review. Expert Rev Endocrinol Metab 14(1):63-74. https://doi.org/10.1080/17446651. 2018.1476135

10. Franzago M, Fraticelli F, Stuppia L, Vitacolonna E (2019) Nutrigenetics, epigenetics and gestational diabetes: consequences in mother and child. Eigenetics 14(3):215-235 https://doi.org/10.1080/15592294.2019.1582277

11. Hod M, Kapur A, Sacks A et al (2015) The international Federation of Gynecology and Obstetrics (FIGO). Initiative on gestational diabetes mellitus: a pragmatic guide for diagnosis, management, and care. J Gynecol Obstet 131(Suppl 3):S173-S211

12. Diabetes G International Diabetes Federation - Home. Available online at www.idf.org/our-activities/care-prevention/gdm

13. Zhao J1, Weiler HA. Long-term effects of gestational diabetes on offspring health are more pronounced in skeletal growth than body composition and glucose tolerance. Br J Nutr, 2010;104(11):1641-9. doi: 10.1017/ S0007114510002631.

14. Damm P1, Houshmand-Oeregaard A, Kelstrup L, et al. Gestational diabetes mellitus and long-term consequences for mother and offspring: a view from Denmark. Diabetologia, 2016;59 (7):1396-1399. doi: https://doi.org/10. 1007/s00125-016-3985-5

15. Clausen TD, Mathiesen ER, Hansen T et al (2008) High prevalence of type 2 diabetes and pre-diabetes in adult offspring of women with gestational diabetes mellitus or type 1 diabetes: the role of intrauterine hyperglycemia. Diabetes Care 31:340-346. https://doi.org/10.2337/dc07-1596

16. Assche FAV, Holemans $K$, Aerts L (2011) Long-term consequences for offspring of diabetes during pregnancy. British Medical Bulletin 60(1):173182 https://doi.org/10.1093/bmb/60.1.173

17. International Diabetes Federation. Diabetes Atlas 8th ed., 2017. Available online at http://fmdiabetes.org/wp-content/uploads/2018/03/IDF-2017.pdf

18. Kaaja R, Rönnemaa T (2008) Gestational Diabetes: Pathogenesis and Consequences to Mother and Offspring. Rev Diabet Stud. 5(4):194-202. https://doi.org/10.1900/RDS.2008.5.194

19. Shu L, Sauter NS, Schulthess FT, Matveyenko AV, Oberholzer. Transcription factor 7-like 2 regulates beta-cell survival and function in human pancreatic islets. Diabetes, 2008; 57: 645-653.

20. MacDonald PE, Ha XF, Wang J, Smukler SR, Sun AM, Gaisano HY (2001) Members of the Kv1 and Kv2 voltage-dependent $K(+)$ channel families regulate insulin secretion. Mol Endocrinol 15(8):1423-1435. https://doi.org/ 10.1210/mend.15.8.0685

21. Huerta-Chagoya A, Vázquez-Cárdenas P, Moreno-Macías H, Tapia-Maruri L, Rodríguez-Guillén R, López-Vite E (2015) Genetic determinants for gestational diabetes mellitus and related metabolic traits in Mexican women. PloS one 10(5):e0126408. https://doi.org/10.1371/journal.pone. 0126408

22. Prokopenko I, Langenberg C, Florez JC et al (2009) Variants in MTNR1B influence fasting glucose levels. Nature genetics 41(1):77-81. 19060907

23. Shang M, Wen Z (2018) Increased placental IGF-1/mTOR activity in macrosomia born to women with gestational diabetes. Diabetes Research and Clinical Practice 146:211-219 https://doi.org/10.1016/j.diabres.2018.10. 017

24. Casellas A, Mallol C, Salavert A, Jimenez V, Garcia M, Agudo J (2015) Insulinlike Growth Factor 2 Overexpression Induces $\beta$-Cell Dysfunction and Increases Beta-cell Susceptibility to Damage. The Journal of Biological Chemistry 290:16772-16785. https://doi.org/10.1074/jbc.M115.642041

25. Ramirez VI, Miller E, Meireles CL, Gelfond J, Krummel DA, Powell TL (2014) Adiponectin and IGFBP-1 in the development of gestational diabetes in obese mothers. BMJ Open Diabetes Research and Care 2:e000010. https:// doi.org/10.1136/ bmjdrc-2013-000010

26. DeMambro VE, Clemmons DR, Horton LG, Bouxsein ML, Wood TL, Beamer WG (2008) Gender-specific changes in bone turnover and skeletal architecture in IGFBP2-null mice. Endocrinology 149:2051-2061. https://doi. org/10.1210/en.2007-1068

27. Chon SJ, Kim SY, Cho NR, Min DL, Hwang YJ, Mamura M (2013) Association of variants in PPARY ${ }^{2}$, IGF2BP2, and KCNQ1 with a susceptibility to gestational diabetes mellitus in a Korean population. Yonsei Medical Journal 54(2):352-357. https://doi.org/10.3349/ymj.2013.54.2.352

28. Schwanstecher C, Meyer U, Schwanstecher M (2002) K(IR)6.2 polymorphism predisposes to type 2 diabetes by inducing overactivity of pancreatic betacell ATP-sensitive $\mathrm{K}(+)$ channels. Diabetes 51:875-879. https://doi.org/10. 2337/diabetes.51.3.875

29. Ober C, Xiang KS, Thisted RA, Indovina KA, Wason CJ, Dooley S (1989) Increased risk for gestational diabetes mellitus associated with insulin receptor and insulin-like growth factor II restriction fragment length polymorphisms. Genet Epidemiol 6:559-569

30. Ceasrine AM, Lin EE, Lumelsky DN, lyer R, Kuruvilla R (2018) Adrb2 controls glucose homeostasis by developmental regulation of pancreatic islet vasculature. ELife 7:e39689. https://doi.org/10.7554/eLife.39689

31. Guan L, Cui X, Zhou H (2018) Meta-analysis of the association between the Trp64Arg polymorphism of the beta-3 adrenergic receptor and susceptibility to gestational diabetes mellitus. J Obstet Gynaecol 38(2):172176. https://doi.org/10.1080/01443615.2017.1331339

32. Feng $Y$, Jiang $C D$, Chang $A M$ et al (2019) Interactions among insulin resistance, inflammation factors, obesity-related gene polymorphisms, environmental risk factors, and diet in the development of gestational diabetes mellitus. J Matern Fetal Neonatal Med. 32(2):339-347. https://doi. org/10.1080/14767058.2018.1446207

33. Kapoor RR, Flanagan SE, James CT, McKiernan J, Thomas AM, Harmer SC (2011) Hyperinsulinaemic hypoglycaemia and diabetes mellitus due to dominant ABCC8/KCNJ11 mutations. Diabetologia 54(10):2575-2583. https:// doi.org/10.1007/s00125-011-2207-4

34. Castro-Martínez AG, Sánchez-Corona J, Vázquez-Vargas AP, García-Zapién AG, López-Quintero A, Villalpando-Velazco HJ. Association analysis of calpain 10 gene variants/haplotypes with gestational diabetes mellitus among Mexican women. Cell Mol Biol (Noisy-le-grand). 2018; 28;64(3):81-86. doi: https://doi.org/10.14715/cmb/2018.64.3.13.

35. Megia A, Gallart L (2004) Fernández-Real J-M, Vendrell J, Simón I, Gutierrez C. Mannose-Binding Lectin Gene Polymorphisms Are Associated with Gestational Diabetes Mellitus. The Journal of Clinical Endocrinology \& Metabolism 89(10):5081-5087 https://doi.org/10.1210/jc.2004-0211

36. Catalano PM (2014) Trying to understand gestational diabetes. Diabet. Med 31:273-281. https://doi.org/10.1111/dme.12381

37. Yang Q, Graham TE, Mody N et al (2005) Serum retinol binding protein 4 contributes to insulin resistance in obesity and type 2 diabetes. Nature 436: 356-362

38. Shimin Hu, Shujuan Ma, Xun Li, et al. Relationships of SLC2A4, RBP4, PCK1, and PI3K Gene Polymorphisms with Gestational Diabetes Mellitus in a Chinese Population. BioMed Research International, 2018; 2019:Article ID 7398063. https://doi.org/10.1155/2019/7398063. 
39. Shimin H, Junxia Y, Yiping Y, Guilian Y, Hui Z, Xun L (2019) Association of polymorphisms in STRA6 gene with gestational diabetes mellitus in a Chinese Han population. Medicine 98(11):e14885. https://doi.org/10.1097/ MD.0000000000014885

40. Zhu B, Huang K, Yan S, et al. VDR Variants rather than Early Pregnancy Vitamin D Concentrations Are Associated with the Risk of Gestational Diabetes: The Ma'anshan Birth Cohort (MABC) Study. J. Diabetes Res, 2019; 2019: Article ID 8313901. https://doi.org/10.1155/2019/8313901.

41. Apaydın M, Beyse S, Eyerci N, Pinarli FA, Ulubay M, Kizilgul M. The VDR gene Fokl polymorphism is associated with gestational diabetes mellitus in Turkish women. BMC Medical Genetics, 2019; 20: Article number: 82. DO https://doi.org/10.1186/s12881-019-0820-0

42. Wang K, Chen Q, Feng Y, et al. Single Nucleotide Polymorphisms in CDKAL1 Gene Are Associated with Risk of Gestational Diabetes Mellitus in Chinese Population. J Diabetes Res, 2019; 2019: Article ID 3618103. https://doi.org/ 10.1155/2019/3618103.

43. Okruszko A, Kinalski M, Kuźmicki M, Mirończuk K, Wawrusiewicz-Kurylonek N, Kretowski KIA (2007) Glucokinase gene mutations in gestational diabetes in Polish population. Prediction of diabetes mellitus development after delivery. Przegl Lek 64(6):401-405

44. Mei J, Liao S, Liu Y, Tan Y, Wang H, Liang Y (2015) Association of variants in CDKN2A/2B and CDKAL1 genes with gestational insulin sensitivity and disposition in pregnant Han Chinese women. J Diabetes Investig 6(3):295301. https://doi.org/10.1111/jdi.12315

45. Wang Y, Nie M, Li W et al (2011) Association of Six Single Nucleotide Polymorphisms with Gestational Diabetes Mellitus in a Chinese Population. PLOS ONE 6(11):e26953 https://doi.org/10.1371/journal.pone.0026953

46. Cho YM, Kim TH, Lim S, Choi SH, Shin HD, Lee HK (2009) Type 2 diabetesassociated genetic variants discovered in the recent genome-wide association studies are related to gestational diabetes mellitus in the Korean population. Diabetol 52:253-261. https://doi.org/10.1007/s00125-008-1196-4

47. Seman NA, Mohamud WN, Östenson CG, et al. Increased DNA methylation of the SLC30A8 gene promoter is associated with type 2 diabetes in a Malay population. Clin. Epigenetics, 2015; 7: 30. https://doi.org/10.1186/ s13148-015-0049-5.

48. Marcello MA, Calixto AR, de Almeida JF, et al. Polymorphism in LEP and LEPR May Modify Leptin Levels and Represent Risk Factors for Thyroid Cancer. Int. J. Endocrinol. 2015: 173218. https://doi.org/10.1155/2015/ 173218.

49. Lin R, Ju H, Yuan Z, Zeng L, Sun Y, Su Z (2017) Association of maternal and fetal LEPR common variants with maternal glycemic traits during pregnancy. Sci Rep 7(1):3112. https://doi.org/10.1038/s41598-017-03518-x

50. Watanabe $\mathrm{RM}$, Xiang $\mathrm{AH}$, Allayee $\mathrm{H}$, et al. Variation in the P2-promoter region of hepatocyte nuclear factor-4a (HNF4A) is associated with B-cell function in Mexican American families of a proband with gestational diabetes. Diabetes, 2005; 54 (supplement 1): A28.

51. Ridderstråle M, Groop L (2009) Genetic dissection of type 2 diabetes. Molecular and Cellular Endocrinology 297(1-2):10-17

52. Ategbo JM, Grissa O, Yessoufou A, Hichami A, Dramane KL, Moutairou K (2006) Modulation of adipokines and cytokines in gestational diabetes and macrosomia. J Clin Endocrinol Metab. 91:4137-4143

53. Toppings NB, McMillan JM, Au P, Suchowersky O, Donovan LE. Wolfram Syndrome: A Case Report and Review of Clinical Manifestations, Genetics Pathophysiology, and Potential Therapies. Case Reports in Endocrinol, 2018; 2018: Article ID 9412676 doi:https://doi.org/10.1155/2018/9412676.

54. Vana DR, Adapa D, Prasad VSS, Choudhury A, Ahuja G. Diabetes mellitus types: Key genetic determinants and risk assessment. Genet Mol Res, 2019; 18 (2): gmr16039952.

55. Kwak SH, Park BL, Kim H, German MS, Go MJ, Jung HS. Association of Variations in TPH1 and HTR2B with Gestational Weight Gain and Measures of Obesity. Obesity, 2012; 20 (1). https://doi.org/10.1038/oby. 2011.253

56. Oh CM, Park S, Kim H (2016) Serotonin as a New Therapeutic Target for Diabetes Mellitus and Obesity. Diabetes Metab J 40(2):89-98. https://doi. org/10.4093/dmj.2016.40.2.89

57. Beysel S, Eyerci N, Ulubay M, Caliskan M, Kizilgul M, Hafizoğlu M. Maternal genetic contribution to pre-pregnancy obesity, gestational weight gain, and gestational diabetes mellitus. Diabetol Metabol Synd, 2019; 11: Article number: 37. https://doi.org/10.1186/s13098-019-0434-x

58. Pollin TI, Jablonski KA, McAteer JB et al (2011) Triglyceride response to an intensive lifestyle intervention is enhanced in carriers of the GCKR
Pro446Leu polymorphism. J Clin Endocrinol Metab 96:E1142-E1147. https:// doi.org/10.1210/jc.2010-2324

59. Grimsby J, Coffey JW, Dvorozniak MT, Magram J, Li G, Matschinsky FM. Characterization of glucokinase regulatory protein-deficient mice. J Biol Chem, 2000; 275 :7826 -7831. doi: https://doi.org/10.1074/jbc.275.11.7826

60. Zheng L, Li C, Qi WH et al (2017) Expression of macrophage migration inhibitory factor gene in placenta tissue and its correlation with gestational diabetes mellitus. Zhonghua yi xue za zhi 97:3388-3391

61. Kawai VK, Levinson RT, Adefurin A, Kurnik D, Collier SP, Conway D (2017) Variation in the a2A-adrenergic receptor gene and risk of gestational diabetes. Pharmacog 18(15):1381-1386. https://doi.org/10.2217/pgs-20170079

62. Leitner M, Fragner L, Danner S, Holeschofsky N, Leitner K, Tischler S (2017) Combined metabolomic analysis of plasma and urine reveals AHBA, Tryptophan and Serotonin metabolism as potential risk factors in Gestational Diabetes Mellitus (GDM). Front Mol Biosci 4:84. https://doi.org/ 10.3389/fmolb.2017.00084

63. Beysel S, Eyerci N, Ulubay M, Caliskan M, Kizilgul M, Hafızoğlu M. Maternal genetic contribution to pre-pregnancy obesity, gestational weight gain, and gestational diabetes mellitus. Diabetol Metab Synd, 2019; 11: Article number: 37. https://doi.org/10.1186/s13098-019-0434-x

64. Mellado-Gil JM, Fuente-Martín E, Lorenzo PI, Cobo-Vuilleumier N, LópezNoriega L, Martín-Montalvo, A. The type 2 diabetes-associated HMG20A gene is mandatory for islet beta cell functional maturity. Cell Death \& Disease, 2018; 9: Article number: 279.

65. Hodson DJ, Mitchell RK, Marselli L, Pullen TJ, Gimeno Brias S, Semplici F (2014) ADCY5 couples glucose to insulin secretion in human islets. Diabetes 63(9):3009-3021. https://doi.org/10.2337/db13-1607

66. Mojtaba E, Mahdi K, Mehdi KJR, Amir S (2011) Serum interleukin-1 beta plays an important role in insulin secretion in type II diabetic. Inter J Bio 1(3):93-99

67. Meier JJ, Ritzel RA, Maedler K, Gurlo T, Butler PC (2006) Increased vulnerability of newly forming beta cells to cytokine-induced cell death. Diabetolog 49:83-89. https://doi.org/10.1007/s00125-005-0069-3

68. Kang J, Liu C-H, Lee C-N, Li H-Y, Yang C-W, Huang S-C (2019) Novel Interleukin-10 Gene Polymorphism Is Linked to Gestational Diabetes in Taiwanese Population. Front. Genet 10:89. https://doi.org/10.3389/fgene. 2019.00089

69. Martin-Montalvo A, López-Noriega L, Jiménez-Moreno C, Herranz A, Lorenzo PI, Cobo-Vuilleumier N (2019) Transient PAX8 Expression in Islets During Pregnancy Correlates With $\beta$-Cell Survival, Revealing a Novel Candidate Gene in Gestational Diabetes Mellitus. Diabetes 68(1):109-118 https://doi. org/10.2337/db18-0285

70. Takhshid MA, Haem Z, Aboualizadeh F (2015) The association of circulating adiponectin and $+45 \mathrm{~T} / \mathrm{G}$ polymorphism of adiponectin gene with gestational diabetes mellitus in Iranian population. J Diabetes Metab Disord 14:30. https://doi.org/10.1186/s40200-015-0156-z

71. Hasanvand Z, Sadeghi A, Rezvanfar MR, Goodarzi MT, Rahmannezhad G, Mashayekh FJ (2018) Association between chemerin rs17173608 and rs4721 gene polymorphisms and gestational diabetes mellitus in Iranian pregnant women. Gene 649:87-92 https://doi.org/10.1016/j.gene.2018.01.061

72. Ademoglu E, Berberoglu Z, Dellal FD, Ariel MK, Kose A, Candan Z. Higher Levels of Circulating Chemerin in Obese Women with Gestational Diabetes Mellitus. Acta Endocrinologica (Buc), 2015; XI (1): 32-37. doi: https://doi.org/ 10.4183/aeb.2015.32.

73. Steppan CM, Bailey ST, Bhat S et al (2001) The hormone resistin links obesity to diabetes. Nature 409:307-312

74. Aslan M, Celik O, Celik N et al (2012) Cord blood nesfatin-1 and apelin-36 levels in gestational diabetes mellitus. Endocrine 41:424-429

75. Franz M, Polterauer M, Springer S, Kuessel L, Haslinger P, Worda C (2018) Maternal and neonatal omentin-1 levels in gestational diabetes. Arch gynecol obst 297(4):885-889. https://doi.org/10.1007/s00404-018-4652-5

76. Ferreira AF, Rezende JC, Vaikousi E et al (2011) Maternal serum visfatin at 11-13 weeks of gestation in gestational diabetes mellitus. Clin Chem 57: 609-613

77. Mellado-Gil JM, Fuente-Martín E, Lorenzo PI, Cobo-Vuilleumier N, LópezNoriega L, Martín-Montalvo A. The type 2 diabetes-associated HMG20A gene is mandatory for islet beta cell functional maturity. Cell Death \& Disease, 2018; 9:Article number: 279.

78. Ding $M$, Chavarro J, Olsen S, Lin Y, Ley SH, Bao W. Genetic variants of gestational diabetes mellitus: a study of 112 SNPs among 8722 women in 
two independent populations. Diabetolog, 2018; 61 (8): 1758-1768. https:// doi.org/10.1007/s00125-018-4637-8

79. Khan IA, Shaik NA, Pasupuleti N, Chav S, Jahan P, Hasan Q (2015) Screening of mitochondrial mutations and insertion-deletion polymorphism in gestational diabetes mellitus in the Asian Indian population. Saudi J Bio Sci 22(3):243-248 https://doi.org/10.1016/.j.jbs.2014.11.001

80. Banerjee RR, Cyphert HA, Walker EM, Chakravarthy H, Peiris H, Gu X (2016) Gestational Diabetes Mellitus From Inactivation of Prolactin Receptor and MafB in Islet $\beta$-Cells. Diabetes 65(8):2331-2341. https://doi.org/10.2337/ db15-1527

81. Zha W, Ho HTB, Hu T, Hebert MF, Wang MJ. Serotonin transporter deficiency drives estrogen-dependent obesity and glucose intolerance. Sci Rep, 2017; 7: Article number: 1137. DOl https://doi.org/10.1038/s41598-01701291-5.

82. Leipold H, Knoefler M, Gruber C, Klein K, Haslinger P, Worda C (2006) Plasminogen activator inhibitor 1 gene polymorphism and gestational diabetes mellitus. Obstet Gynecol 107(3):651-656. https://doi.org/10.1097/ 01.AOG.0000199953.27961.f9

83. Stuebe AM, Wise A, Nguyen T, Herring A, North KE, Siega-Riz AM (2014) Maternal genotype and gestational diabetes. Am J Perinatol. 31(1):69-76. https://doi.org/10.1055/s-0033-1334451

84. Chagnon MJ, Elchebly M, Uetani N, Dombrowski L, Cheng A, Mooney RA (2006) Altered glucose homeostasis in mice lacking the receptor protein tyrosine phosphatase sigma. Can J Physiol Pharmacol 84:755-763. https:// doi.org/10.1139/y06-020

85. Alamolhoda SH, Yazdkhasti M, Namdari M, Zakariayi SJ, Mirabi P (2019) Association between C-reactive protein and gestational diabetes: a prospective study. J Obstet Gynaecol 9:1-5. https://doi.org/10.1080/ 01443615.2019 .1631767

86. Zhang YH, Van Hove JL, McCabe ER, Dipple KM (2015) Gestational Diabetes Associated with a Novel Mutation (378-379insTT) in the Glycerol Kinase Gene. Mol Genet Metab Rep 4:42-45. https://doi.org/10.1016/j.ymgmr.2015. 06.004

87. Xu T, Shi Y, Liu J, Liu Y, Zhu A, Xie C (2017) The rs 10229583 polymorphism near paired box gene 4 is associated with gestational diabetes mellitus in Chinese women. J Inter Med Res 46(1):116-121. https://doi.org/10.1177/ 0300060517714934

88. Gong M, Yu Y, Liang L, Vuralli D, Froehler S, Kuehnen P (2019) HDAC4 mutations cause diabetes and induce $\beta$-cell FoxO1 nuclear exclusion. Mol Genet Gen med 7(5):e602. https://doi.org/10.1002/mgg3.602

89. Farhan S, Handisurya A, Todoric J, Tura A, Pacini G, Wagner O (2012) FetuinA Characteristics during and after Pregnancy: Result from a Case Control Pilot Study. Inter J endocrinol 896736. https://doi.org/10.1155/2012/896736

90. Kralisch S, Hoffmann A, Lössner U (2017) Kratzsch J3, Blüher M, Stumvoll M. Regulation of the novel adipokines/ hepatokines fetuin A and fetuin B in gestational diabetes mellitus. Metab 68:88-94. https://doi.org/10.1016/j. metabol.2016.11.017

91. Bonakdaran S, Khorasani ZM, Jafarzadeh F (2017) Increased Serum Level of Fgf21 in Gestational Diabetes Mellitus. Acta Endocrinol 13(3):278-281. https://doi.org/10.4183/aeb.2017.278

92. Xie K, Chen T, Zhang Y, Wen J, Cui X, You L. Association of rs 10830962 polymorphism with gestational diabetes mellitus risk in a Chinese population. Sci Rep, 2019; 9:Article number: 5357. DOI https://doi.org/10 1038/s41598-019-41605-3

93. Huerta-Chagoya A, Vázquez-Cárdenas P, Moreno-Macías H et al (2015) Genetic Determinants for Gestational Diabetes Mellitus and Related Metabolic Traits in Mexican Women. PLoS ONE 10(5):e0126408 https://doi. org/10.1371/journal.pone.0126408

94. Wu L, Cui L, Tam W et al (2016) Genetic variants associated with gestational diabetes mellitus: a meta-analysis and subgroup analysis. Sci Rep 6:30539. https://doi.org/10.1038/srep30539

95. Shaat N, Lernmark A, Karlsson E et al (2007) A variant in the transcription factor 7-like 2 (TCF7L2) gene is associated with an increased risk of gestational diabetes mellitus. Diabetologia 50:972-979

96. Adeyemo AA, Zaghloul NA, Chen G et al (2019) ZRANB3 is an Africanspecific type 2 diabetes locus associated with beta-cell mass and insulin response. Nat Commun 10:3195. https://doi.org/10.1038/s41467-019-10967-7

97. Lin P-C, Lin W-T, Yeh Y-H, Wung S-F (2016) Transcription Factor 7-Like 2 (TCF7L2) rs7903146 Polymorphism as a Risk Factor for Gestational Diabetes Mellitus: A Meta-Analysis. PLoS One 11(4):e0153044 https://doi.org/10.1371/ journal.pone.0153044
98. Lauenborg J, Grarup N, Damm P et al (2009) Common Type 2 Diabetes Risk Gene Variants Associate with Gestational Diabetes. J Clin Endocrinol \& Metab 94(1):145-150 https://doi.org/10.1210/jc.2008-1336

99. Kawai VK, Levinson RT, Adefurin A et al (2017) A genetic risk score that includes common type 2 diabetes risk variants is associated with gestational diabetes. Clin Endocrinol 87(2):149-155. https://doi.org/10. 1111/cen.13356

100. Kwak SH, Kim TH, Cho YM, Choi SH, Jang HC, Park KS (2010) Polymorphisms in KCNQ1 are associated with gestational diabetes in a Korean population. Horm Res Paediatr. 74:333-338

101. Fatima SS, Chaudhry B, Khan TA, Farooq S. KCNQ1 rs2237895 polymorphism is associated with Gestational Diabetes in Pakistani Women. Pak J Med Sci. 2016 Nov-Dec;32(6):1380-1385. doi: https://doi.org/10.12669/pjms.326.11052.

102. Kwak SH, Jang HC, Park KS (2012) Finding Genetic Risk Factors of Gestational Diabetes. Genomics Inform. 10(4):239-243. https://doi.org/10. 5808/GI.2012.10.4.239

103. Ding M (2018) Chavarro J1, Olsen S, Lin Y, Ley SH1, Bao W, et al. Genetic Variants of Gestational Diabetes Mellitus: a Study of 112 SNPs Among 8,722 Women in Two Independent Populations. Diabetologia. 61(8):1758-1768. https://doi.org/10.1007/s00125-018-4637-8

104. Alharbi KK, Al-Sulaiman AM, Bin Shedaid MK, et al. MTNR1B genetic polymorphisms as risk factors for gestational diabetes mellitus: a casecontrol study in a single tertiary care center. Ann Saudi Med. 2019; 39(5): 309-318. doi: https://doi.org/10.5144/0256-4947.2019.309.

105. Mansoori Y, Daraei A, Naghizadeh MM, Salehi R (2015) Significance of a common variant in the CDKAL1 gene with susceptibility to type 2 diabetes mellitus in Iranian population. Adv Biomed Res 4:45. https://doi.org/10.4103/ 2277-9175.151256

106. Shaat N, Ekelund M, Lernmark A et al (2005) Association of the E23K polymorphism in the KCNJ11 gene with gestational diabetes mellitus. Diabetolog 48:2544-2551

107. Fallucca F, Dalfra MG, Sciullo E et al (2006) Polymorphisms of insulin receptor substrate 1 and beta3-adrenergic receptor genes in gestational diabetes and normal pregnancy. Metab 55:1451-1456

108. Alharbi KK, Khan IA, Abotalib Z, Al-Hakeem MM. Insulin Receptor Substrate-1 (IRS-1) Gly927Arg: Correlation with Gestational Diabetes Mellitus in Saudi Women. BioMed Res Intern, 2014, Article ID 146495. https://doi.org/10.1155/ 2014/146495.

109. Rosta K, Al-Aissa Z, Hadarits O et al (2017) Association study with 77 SNPs confirms the robust role for the rs $10830963 / \mathrm{G}$ of MTNR1B variant and identifies two novel associations in gestational diabetes mellitus development. PLoS One 12:e0169781

110. Cho YM, Kim TH, Lim S et al (2009) Type 2 diabetes-associated genetic variants discovered in the recent genome-wide association studies are related to gestational diabetes mellitus in the Korean population. Diabetolog 52(2):253-261

111. Wang Y, Nie M, Li W et al (2011) Association of six single nucleotide polymorphisms with gestational diabetes mellitus in a Chinese population. PloS One 6(11):e26953

112. Lauenborg J, Grarup N, Damm P et al (2009) Common type 2 diabetes risk gene variants associate with gestational diabetes. J Clin Endocrinol Metab 94(1):145-150

113. Stuebe A, Wise A, Nguyen T, Herring A, North K, Siega-Riz A (2013) Maternal Genotype and Gestational Diabetes. Am. J. Perinatol. 31:069-076

114. Jamalpour S, Zain SM, Mosavat M, Mohamed Z, Omar S.Z. A case-control study and meta-analysis confirm glucokinase regulatory gene rs780094 is a risk factor for gestational diabetes mellitus. Gene 2018, 650, 34-40.

115. Anghebem-Oliveira MI, Webber S, Alberton D et al (2017) The GCKR Gene Polymorphism rs780094 is a Risk Factor for Gestational Diabetes in a Brazilian Population. J. Clin. Lab. Anal 31:e22035

116. Bonakdaran S, Khorasani ZM, Jafarzadeh F (2017) Increased Serum Level of Fgf21 in Gestational Diabetes Mellitus. Acta Endocrinol (Buchar). 13(3):278281. https://doi.org/10.4183/aeb.2017.278

117. Chen C, Cheung BM, Tso AW et al (2011) High plasma level of fibroblast growth factor 21 is an Independent predictor of type 2 diabetes: a 5.4-year population-based prospective study in Chinese subjects. Diabetes Care. 34(9):2113-2115. https://doi.org/10.2337/dc11-0294

118. Nitert D, Barrett HL, Kubala MH et al (2014) Increased Placental Expression of Fibroblast Growth Factor 21 in Gestational Diabetes Mellitus. J Clin Endocrinol \& Metab 99(4):E591-E598 https://doi.org/10. 1210/jc.2013-2581 
119. Rissanen J, Markkanen A, Karkkainen P et al (2000) Sulfonylurea receptor 1 gene variants are associated with gestational diabetes and type 2 diabetes but not with altered secretion of insulin. Diabetes Care 23:70-73

120. Hasanvand Z, Sadeghi A, Rezvanfar MR, Goodarzi MT, Rahmannezhad G, Mashayekhi FJ (2018) Association between chemerin rs17173608 and rs4721 gene polymorphisms and gestational diabetes mellitus in Iranian pregnant women. Gene. 649:87-92. https://doi.org/10.1016/j.gene.2018.01.061

121. Litou $H$, Anastasiou $E$, Thalassinou L et al (2007) Increased prevalence of VNTR III of the insulin gene in women with gestational diabetes mellitus (GDM). Diabetes Res Clin Pract 76:223-228

122. Handy DE, Castro R, Loscalzo J (2011) Epigenetic Modifications: Basic Mechanisms and Role in Cardiovascular Disease. Circulation. 123(19):21452156. https://doi.org/10.1161/CIRCULATIONAHA.110.956839

123. Feil R, Fraga MF (2011) Epigenetics and the environment: Emerging patterns and implications. Nat Rev Genet 13:97-109. https://doi.org/10.1038/nrg3142

124. Ordovas JM, Smith CE (2010) Epigenetics and cardiovascular disease. Nat Rev Cardiol 7:510-519. https://doi.org/10.1038/nrcardio.2010.104

125. Stankov K, Benc D, Draskovic D (2013) Genetic and epigenetic factors in etiology of diabetes mellitus type 1. Pediatr 132:1112-1122

126. Xie Z, Chang C, Zhou Z (2014) Molecular mechanisms in autoimmune type 1 diabetes: a critical review. Clin Rev Allergy Immunol 47:174-192

127. Kimmins S, Sassone-Corsi $P$ (2005) Chromatin remodelling and epigenetic features of germ cells. Nature 434(7033):583-589

128. Kang J, Lee C-N, Li H-Y, Hsu K-H, Wang S-H, Lin S-Y (2018) Association of Interleukin-10 Methylation Levels With Gestational Diabetes in a Taiwanese Population. Front Genet 9:222. https://doi.org/10.3389/fgene.2018.00222

129. Jacovetti C, Abderrahmani A, Parnaud G, Jonas JC, Peyot ML, Cornu M (2012) MicroRNAs contribute to compensatory $\beta$ cell expansion during pregnancy and obesity. J Clin Invest 122(10):3541-3551. https://doi.org/10. $1172 / J C 164151$

130. Stirm L, Huypens P, Sass S, Batra R, Fritsche L, Brucker S. Maternal whole blood cell miRNA-340 is elevated in gestational diabetes and inversely regulated by glucose and insulin. Sci Rep, 2018; 8:1366-1378. | DOl:https:// doi.org/10.1038/s41598-018-19200-9.

131. Jo H, Eckel SP, Chen J-C, Cockburn M, Martinez MP, Chow T (2019) Associations of gestational diabetes mellitus with residential air pollution exposure in a large Southern California pregnancy cohort. Environ Inter 130: 104933-104939 https://doi.org/10.1016/j.envint.2019.104933

132. Lodovici M, Bigagli E. Oxidative stress and air pollution exposure. J Toxicol, 2011; (2011): Article 487074

133. Saldana TM, Basso O, Hoppin JA, Baird DD, Knott C, Blair A (2007) Pesticide Exposure and Self-Reported Gestational Diabetes Mellitus in the Agricultural Health Study. Diabetes Care 30(3):529-534. https://doi.org/10.2337/dc061832

134. Vu BG, Stach CS, Kulhankova K, Salgado-Pabón W, Klingelhutz AJ, Schlievert PM. Chronic Superantigen Exposure Induces Systemic Inflammation, Elevated Bloodstream Endotoxin, and Abnormal Glucose Tolerance in Rabbits: Possible Role in Diabetes. mBio, 2015; 6 (2): e02554-14 DOl: https:// doi.org/10.1128/mBio.02554-14.

135. Crusell MKW, Hansen TH, Nielsen T, Allin KH, Rühlemann MC, Damm P (2018) Gestational diabetes is associated with change in the gut microbiota composition in third trimester of pregnancy and postpartum. Microbiome 6 89 https://doi.org/10.1186/s40168-018-0472-x

136. Mokkala K, Röytiö H, Munukka E, Pietilä S, Ekblad U, Rönnemaa T (2016) Gut Microbiota Richness and Composition and Dietary Intake of Overweight Pregnant Women Are Related to Serum Zonulin Concentration, a Marker for Intestinal Permeability. J Nutr 146(9):1694-1700. https://doi.org/10.3945/jn. 116.235358

137. Duke-NUS Medical School. Association between insufficient sleep, gestational diabetes mellitus discovered. ScienceDaily. www.sciencedaily. com/releases/2017/01/170109092634.htm (accessed October 26, 2019).

138. Mak JKL, Pham NM, Lee AH, Tang L, Pan X-F, Binns CW. Dietary patterns during pregnancy and risk of gestational diabetes: a prospective cohort study in Western China. Nutr J, 2018; 17:Article number: 107. DOl https://doi. org/10.1186/s12937-018-0413-3

139. Cai D, Liu H, Hu Y, Jiang Y, Zhao R Gestational Betaine, Liver Metabolism, and Epigenetics. In: Patel V., Preedy V. (eds) Handbook of Nutrition, Diet, and Epigenetics. Springer, Cham. 2017. DOl https://doi.org/10.1007/978-3319-31143-2_82-1

140. Sivitz W. Mltochondrial Dysfunction in Obesity and Diabetes. US Endocrinol, 2010; 6 (1): 20-27 DOl: https://doi.org/10.17925/USE.2010.06.1.20.
141. R"onn T, Poulsen P, Hansson O, et al. Age influences DNA methylation and gene expression of COX7A1 in human skeletal muscle. Diabetolog, 2008; 51 : 1159\{1168. DOl: https://doi.org/10.1007/s00125-008-1018-8.

142. Makgoba M, Savvidou M, Steer P (2012) An analysis of the interrelationship between maternal age, body mass index and racial origin in the development of gestational diabetes mellitus. BJOG 119:276-282. https:// doi.org/10.1111/j.1471-0528.2011.03156.x

143. Ming W, Ding W, Zhang CJP, Zhong L, Long Y, Li Z. The effect of exercise during pregnancy on gestational diabetes mellitus in normal-weight women: a systematic review and meta-analysis. BMC Pregnancy and Childbirth, 2018; 18: Article number: 440. DOl https://doi.org/10.1186/ s12884-018-2068-7.

144. Eriksson KF, Lindg"arde F. Poor physical fitness, and impaired early insulin response but late hyperinsulinaemia, as predictors of NIDDM in middleaged Swedish men. Diabetolog, 1996; 39:573-579.

145. Grazioli E, Dimauro I, Mercatelli N et al (2017) Physical activity in the prevention of human diseases: role of epigenetic modifications. BIC Genomics 18(Suppl 8):802. https://doi.org/10.1186/s12864-017-4193-5

146. World Health Organization. Diagnostic criteria and classification of hyperglycaemia first detected in pregnancy. Geneva:; 2013. http://www. who.int/diabetes/publications/Hyperglycaemia_In_Pregnancy/en/

147. United Kingdom National Health Service. Overview: Gestational Diabetes. Updated 2019. Available at https:/mww.nhs.uk/conditions/gestational-diabetes/.

148. United States National Institute of Health. Tests \& Diagnosis for Gestational Diabetes. Updated 2017. Available at https://www.niddk.nih.gov/healthinformation/diabetes/overview/what-is-diabetes/gestational/tests-diagnosis

149. Farghaly TA, Helmy NA, Abbas AM, Ahmed AGM C-reactive protein as a screening test for gestational diabetes mellitus in first-trimester of pregnancy: a prospective cohort study. Int J Reprod Contracept Obstet Gynecol, 2018;7:4798-803. DOl https://doi.org/10.18203/2320-1770. ijrcog20184922

150. Schaible B, Calhoun BC, Bush S, Ramser B, Seybold DJ, Broce M. Hemoglobin A1C as a screening strategy for gestational diabetes. Med Dent Res, 2018: 1 (1): 1-4. DOl: https://doi.org/10.15761/MDR.1000103

151. Fitria N, van Asselt ADI, Postma MJ (2019) Cost-effectiveness of controlling gestational diabetes mellitus: a systematic review. Eur J Health Eco 20(3): 407-417. https://doi.org/10.1007/s10198-018-1006-y

152. Marseille E, Lohse N, Jiwani A, Hod M, Seshiah V, Yajnik CS. The costeffectiveness of gestational diabetes screening including prevention of type 2 diabetes: application of a new model in India and Israel. J Maternal-Fetal \& Neonat Med, 2013; 26 (8). https://doi.org/10.3109/14767058.2013.765845.

153. Saccone G, Caissutti C, Khalifeh MDA, Scifres C, Simhan HN (2017) One Step versus Two Step approach for gestational diabetes screening: systematic review and meta-analysis of the randomized trials. Journal of Maternal-Fetal and Neonat Med 32(8):1-211. https://doi.org/10.1080/14767058.2017.1408068

154. Amreen S, Suneel A, Shetty A, Vasudeva A, Kumar P Use of glycosylated $\mathrm{HbA1C}$ and random blood sugar as a screening tool for gestational diabetes mellitus in first trimester. Int J Reprod Contracept Obstet Gynecol, 2018;7: 524-8. DOl https://doi.org/10.18203/2320-1770.jjrcog20180166

\section{Publisher's Note}

Springer Nature remains neutral with regard to jurisdictional claims in published maps and institutional affiliations.

\section{Submit your manuscript to a SpringerOpen ${ }^{\circ}$ journal and benefit from:}

- Convenient online submission

- Rigorous peer review

- Open access: articles freely available online

High visibility within the field

- Retaining the copyright to your article

Submit your next manuscript at $>$ springeropen.com 